Stefko, R., Jencova, S., Vsanicova, P., \& Litavcova, E. (2019). An Evaluation of Financial Health in the Electrical Engineering Industry. Journal of Competitiveness, 11(4), 144-160. https://doi.org/10.7441/ joc. 2019.04 .10

\title{
AN EVALUATION OF FINANCIAL HEALTH IN THE ELECTRICAL ENGINEERING INDUSTRY
}

\author{
- Robert Stefko, Sylvia Jencova, Petra Vasanicova, Eva Litavcova
}

\begin{abstract}
One of the characteristics of business competitiveness is business performance. Managerial decision making is one of the main factors that can affect the competitiveness of a company. Financial and economic analysis is an inseparable part of financial management in the practice of business entities. The aim of this contribution is to present several models of forecasting the financial situation of companies. By implementing the Taffler model, Springate model, and the Aspect Global Rating, we assess the financial health of a set of non-financial corporations that, with their net turnover, represents almost the entire electrical engineering industry in Slovakia. As Slovakia has a poorly developed capital market and a numerous private companies do not have publicly traded securities, in this paper we use models based on information from financial statements, an approach which is preferable to the use of market-oriented models. Financial data of selected non-financial corporations needed for the financial analysis were obtained from the Register of Financial Statements of the Slovak Republic, with data for the entire industry obtained from the CRIBIS database and results highlighting the financial health of individual electrical engineering companies. Relevant information should be beneficial especially for suppliers in order to avoid disruptions in their own production as well as for stakeholders, managers and auditors. Among other things, it is possible to monitor which companies have the strongest financial health and which are losing their competitiveness, thus are threated. A creditworthy model confirmed that the sector appears to be financially healthy.
\end{abstract}

Keywords: competitiveness, bankruptcy model, creditworthy model, financial analysis, Slovak industry JEL Classification: G3, 016

Received: December, 2018

1st Revision: April, 2019

Accepted: October, 2019

\section{INTRODUCTION}

Informed decision-making by managers has a significant impact on the competitiveness of the company. As is stated in Jencova et al. (2016), one of the characteristics of business competitiveness is business performance. For companies, the issue of competitiveness is highly relevant, especially during the current age of globalization, when even surviving in the market is difficult. Industry competitiveness is not only an important part of the comprehensive competitiveness 
of the country but also a factor influencing its economic development (Yuan-Qiang, 2018). Globalization has significantly influenced the electrical engineering industry as a specific carrier of the latest science and technology results by a synergistic effect which greatly improves the quality of production of other industrial sectors, especially the mechanical engineering industry (Sikula et al., 2003). At present, thanks to foreign investors, Slovakia is once again becoming the center of modern industry in Central Europe. The structure of the economy has not changed significantly for the decade, with one exception being the systematic increase in the share of industrial production and selected professional activities in GDP. On the contrary, the share of public services in GDP is decreasing. The electrical engineering industry represents one of the largest industries in the world, and in Slovakia, this industry together with the mechanical engineering sector embodying the main pillars of industry. The electrical engineering industry in Slovakia has grown at the fastest pace among all manufacturing industries, becoming one of the most attractive industries for foreign investors.

The electrical engineering industry is not created by one or just a few big companies. A large number of medium and small companies have a long tradition. These concerns grow despite the influx of large foreign investors who capitalize Slovakia from abroad. Relevant information regarding the financial health of a company is essential in order to avoid disruption to the firm's production and distribution schedules, especially when long-term contracts with selected suppliers are involved (Agostini, 2018). In addition, predictions and explanations regarding corporate financial health is important for certain stakeholders, managers and auditors. This paper provides an analytical view of the financial health of non-financial corporations in the electrical engineering industry.

The aim of this paper is to determine the financial situation of 138 non-financial corporations in the Slovak electrical engineering industry using two bankruptcy models and one creditworthy model. In addition, the paper briefly describes the Slovak electrical engineering industry as an overall sector of the economy.

\section{THEORETICAL BACKGROUND}

The term competitiveness has a number of definitions depending on the object of research. It can be studied at a microeconomic level with regard to an individual firm, at the level of industry policies, or at the macroeconomic level taking into account the competitive power of a country. At any of these levels, the foundational concept behind competitiveness studies remains the long-term performance of the subject related to its competitors (Vlachvei et al., 2016). As is stated in Chikán (2008), "there is no competitive national economy without competitive companies." "Business performance and industries performance play a crucial role within international competitiveness" (Arslan \& Tathdil, 2012). Therefore, the concept of competitiveness should not be totally explained by only the capacity of a country's productivity, it should also be explained by competitiveness at the level of firm as well as an entire industry. Porter (1980) has claimed that a competitive strategy is based on the attractiveness of the industry in terms of the five competitive forces along with the company's position in the industry. "The basic criterion for a favorable position in the industry is a sustainable competitive advantage" (Fernández et al., 
2019). Every company should always be looking for opportunities to improve and strengthen its market position. Future planning and development forecasting is part of a company's commitment to financial health (Birchall, 2014), while "financial health is an ability to generate a certain level of profitability over a given period" (Vernimmen et al., 2014).

At present, there is a research gap in terms of the links between competitiveness and financial health, with a number of authors pointing out how the area of financial decisions is a determining factor for business competitiveness. Securing appropriate financial information allows the company to analyze investment needs, to determine the optimal capital structure, to regulate dividend policy, and thus to define an overall funding strategy (López Salazar et al., 2012). López Salazar et al. (2012) have noted that "the success or failure of the company influences the results of the entire industry."

\subsection{The Electrical Engineering Industry in the Slovak Republic}

In the area of strengthening industrial production, the cardinal aim is to ensure the optimal use of support to increase industry competitiveness, especially by increasing the efficiency of material and energy recovery through innovation of industrial processes and products. The electrical engineering industry is a priority sector with products of high and medium-high technology and with high value added (Jencova, 2018).

From a historical point of view, Slovakia is and will remain an industrialized state (Jencova et al., 2018). According to Rynik (2018), now one hundred years after establishment of Czechoslovakia, the biggest changes in the development of the Slovak industry have taken place since 1989. First, industry moved to Slovakia from the Czech Republic, then it developed during the formation of factories and from the 1990s on in international markets. By comparison, at the time of the establishment of Czechoslovakia in 1918 Slovakia was predominantly an agrarian region. At that time, only $18 \%$ of the active population worked in the industry, and three fifths in agriculture. Unlike Slovakia, in the Czech-Moravian part of the new state $40 \%$ of the population worked in industry and only $30 \%$ in agriculture. Nevertheless, in Slovakia, some industry did in fact exist after it began to be established in the second half of the 19th century. At that time, the Slovak industry focused mainly on primary production.

Several unique conditions prevail in the Slovak electrical engineering industry, with one of these being that the market economy began development only after 1989. This corresponds, for example, to development in the capital market for the financing of business development. Funding is largely limited to self-financing and loan financing. The possibilities of capital input through stock exchanges or through financing by loan securities are underutilized. Slovak companies have undergone a transformation process, by which a corporate culture and exact management methods, which had largely been absent, was created in these companies. In general, Slovak companies are strongly export-oriented, with many companies focused on targeted areas of economy support that had been realized in the recent past, especially in the automotive and electrical engineering industries, where cyclical swings of the world economy may have a strong correlation with a country's economy. A large part of the economy is specialized in few sectors, creating sustainability risks not only in terms of one particular country sector, but for the country's overall economy. 
The Slovak electrical engineering industry was studied, for example, in Jencova et al. (2016), Jencova et al. (2017), Litavcova et al. (2017). According to the statistics of the European Union, the Slovak Republic is the most industrialized state in the European area. Industrial production is a principal element in ensuring economic growth in Slovakia. In 2016, the share of industry in GDP was $27.92 \%$, the share of industrial production in GDP reached $23.97 \%$, the share of employment in industry in the total employment of the Slovak Republic was $22.85 \%$, and the share of industrial production in the total employment was $20.91 \%$. We can consider this as the highest figure within the European Union. In 2017, compared with the previous period, the employment index for the NACE Rev. 2 group 26 - Manufacture of computer, electronic and optical products decreased from 104.4 percentage points to 98.6 percentage points, for the NACE Rev. 2 group 27 - Manufacture of electrical equipment reached 105.4 percentage points. The baseline labor productivity index and the basic index of sales increased positively. In 2017, revenue in absolute terms reached 9.450 billion EUR, costs were 9.703 billion EUR, and profit (EBT) was 308.26 million EUR. In 2017, 549,807 people worked in the Slovak industry, with 50,830 people working in the electrical engineering industry itself.

In Table 1, we present the NACE Rev. 2 structure of electrical engineering sub-industries of Slovakia.

Tab. 1 - Divisions and subdivisions of electrical engineering industry. Source: own compilation according to Eurostat database (2018)

\begin{tabular}{|l|l|}
\hline \multicolumn{2}{|l|}{ Divisions and subdivisions of electrical engineering industry } \\
\hline 26 & Manufacture of computer, electronic and optical products \\
\hline 26.1 & Manufacture of electronic components and boards \\
\hline & 26.11 Manufacture of electronic components \\
\hline 26.2 & Manufacture of computers and peripheral equipment \\
\hline 26.3 & Manufacture of communication equipment \\
\hline 26.4 & Manufacture of consumer electronics \\
\hline 26.5 & $\begin{array}{l}\text { Manufacture of instruments and appliances for measuring, testing and navigation; } \\
\text { watches and clocks }\end{array}$ \\
\hline & $\begin{array}{l}26.51 \text { Manufacture of instruments and appliances for measuring, testing and naviga- } \\
\text { tion }\end{array}$ \\
\hline & 26.52 Manufacture of watches and clocks \\
\hline 26.6 & Manufacture of irradiation, electromedical and electrotherapeutic equipment \\
\hline 26.7 & Manufacture of optical instruments and photographic equipment \\
\hline 26.8 & Manufacture of magnetic and optical media \\
\hline 27 & Manufacture of electrical equipment \\
\hline 27.1 & $\begin{array}{l}\text { Manufacture of electric motors, generators, transformers and electricity distribution } \\
\text { and control apparatus }\end{array}$ \\
\hline & \begin{tabular}{l}
27.11 Manufacture of electric motors, generators and transformers \\
\hline
\end{tabular} \\
\hline
\end{tabular}




\begin{tabular}{|l|l|}
\hline 27.2 & Manufacture of batteries and accumulators \\
\hline 27.3 & Manufacture of wiring and wiring devices \\
\hline & 27.31 Manufacture of fibre optic cables \\
\hline & 27.32 Manufacture of other electronic and electric wires and cables \\
\hline 27.4 & Manufacture of electric lighting equipment \\
\hline 27.5 & Manufacture of domestic appliances \\
\hline & 27.51 Manufacture of electric domestic appliances \\
\hline & 27.52 Manufacture of non-electric domestic appliances \\
\hline 27.9 & Manufacture of other electrical equipment \\
\hline
\end{tabular}

\subsection{Models of Forecasting in the Financial Analysis}

Companies are largely managed through financial indicators (Dobrovic et al., 2018). The prediction of future development as part of the company's financial assessment requires extending a range of mathematical and statistical methods. Comprehensive business evaluation methods excel because of its transparent but suffer from a lack of precision. It is, therefore, necessary for financial analysts to use several predictive evaluation methods at the same time to identify the financial health of the company.

The issues of forecasting companies' financial health were studied in Kliestik et al. (2018); Kubickova \& Jindrichovska (2015); Neumaierova \& Neimaier (2005); Kamenikova (2005); Bondareva (2011); Kadarova \& Turisova (2011); Vochozka (2011); Malega \& Bjaloncikova (2012); Kabat et al. (2013); Gundova (2012); Kalouda (2016); Belas \& Cipova (2011); El Khoury \& Al Beaino (2014). Widely applied models assessing the financial health of the company are divided into bankruptcy models and creditworthy models. The bankruptcy models help predict the financial distress of companies (Valaskova et al., 2018). Bobinaite (2015) stated that bankruptcy forecasting classifies companies into the categories of bankrupt or non-bankrupt companies taking into account each company's characteristics. Using the creditworthy model, the position of companies within the space is based on two dimensions, namely financial performance and evaluation of enterprise success (Kiseláková et al., 2018). "Creditworthiness risk is the uncertainty surrounding a company's ability to service its debts and obligations" (Benhayoun, 2013, p. 105). Both, bankruptcy and creditworthy models employ the most representative financial ratios (Pavaloaia \& Strimbei, 2015).

There are several models that indicate the financial state of the company and its risk of possible bankruptcy. Linear discriminant analysis models include, for example, the Altman, Springate, and Taffler model. One of the first authors of the bankruptcy model, which is based on logistic regression, was Ohlson (1980). Applications of models using logistic regression can be found in various works. For example, they were used for construction industry of the Czech Republic (Slavicek \& Kubenka, 2016), for construction industry of Lithuania (Harumova \& Janisova, 2014), for small and medium-sized enterprises on the basis of data on enterprises from Presov and Kosice Region of Slovakia (Valecky \& Slivkova, 2012), in a scoring model for Czech companies (Reznakova \& Karas, 2014; Jakubik \& Teply, 2011). 
Currently, there exist many predictive models, but unfortunately, few of them are applicable to Slovak companies, as they were developed in other countries, and for other conditions. In the Czech Republic, there are popular, but little-used models IN95, IN99, IN01, IN05 of Czech authors Neumaier \& Neumaierova (2005), or Kralickov index (Kralicek, 1993). A Beerman discriminatory function is suitable for a manufacturing enterprise. As stated in Baran (2006), in Slovakia, the Altman model (Altman, 2000) is often used as a bankruptcy model, and the Index of creditworthy as a creditworthy model. According to Kislingerova \& Hnilica (2005), there are a lot of methods and approaches to assessing the company's creditworthiness, predicting possible bankruptcy. Financial institutions mostly keep their practices secret because they are their knowhow. However, financial indicators play a crucial role in all models. Complex approaches include sophisticated statistical processes that work with historical time data and calculate the different probabilities of company failure based on certain values of financial indicators. For example, bankruptcy models were described in Bordeianu et al. (2011).

The disadvantage of most models is their focus on the price book value. It is problematic to determine the market value of the company's equity, as the capital market of the Slovak Republic is not developed, and more than $80 \%$ of enterprises have a legal form of Limited Liability Company. In the case of developed economies' capital markets, several studies have confirmed that market-oriented models are better compared to models based on accounting data. However, for the Slovak Republic, which has a poorly developed capital market and a large number of private companies that do not have publicly traded securities, market-oriented models are losing the meaning, and models based on information from financial statements are preferable.

The models of the multiplicative discriminatory analysis reliably describe the financial state of the company. Every financial analyst can generate own model for assessing the financial situation of the business entity. Based on the results of the financial and economic analysis, the financial manager should focus on one aggregate indicator to predict the company's situation.

\section{RESEARCH OBJECTIVE, METHODOLOGY AND DATA}

The main aim of this contribution is to determine the financial situation of 138 non-financial corporations from the Slovak electrical engineering industry, using two bankruptcy models and one creditworthy model.

The basic dataset was made up of 138 companies from the electrical engineering industry of the Slovak Republic. We use financial data of these non-financial corporations for the period from 2012 to 2016. These data were obtained from the Register of Financial Statements of the Slovak Republic. The specific business names of these companies are shown in Table 5.

In this paper, for the purpose of determining the financial situation of non-financial corporations, we use the following prediction models: Taffler model - Zt (1), Springate model - SM (2), Aspect Global Rating model - AGR (3), where used abbreviations mean: EBT - Earnings before Taxes, CL - Current Liabilities, TATR - Total Assets Turnover Ratio, S - Sales, L - Liabilities, A - Assets, NWC - Net Working Capital, EBIT - Earnings before Interests and Taxes, RE Retained Earnings, E - Equity, EBITDA - Earnings Before Interest, Taxes, Depreciation and 
Amortization, EAT - Earnings after Taxes, D - Depreciation, FA - Financial Assets, CR - Current Receivables.

$$
\begin{aligned}
& Z t=0.53 \cdot \frac{E B T}{C L}+0.13 \cdot \frac{T A T R}{L}+0.18 \cdot \frac{C L}{A}+0.16 \cdot \frac{S}{A} \\
& S M=1.03 \cdot \frac{N W C}{A}+3.07 \cdot \frac{E B I T}{A}+0.66 \cdot \frac{E B T}{C L}+0.44 \cdot \frac{S}{A} \\
& A G R=\frac{E B I T D A}{S}+\frac{E A T}{E}+\frac{E B I T}{A}+\frac{S}{A}+\frac{E}{A}+\frac{E B I T+D}{D}+\frac{F A+0.7 \cdot C R}{C L}
\end{aligned}
$$

Therefore, we can say that the financial situation of a company can be evaluated through indicators such as profitability or activity ratios (Rajnoha et al., 2016).

For the Taffler model, if $\mathrm{Zt}>0.3$, there is a low probability of bankruptcy and the company thrives. If $\mathrm{Zt}<0.2$, there is a high probability of bankruptcy. The resulting values in the range of $0.2<\mathrm{Zt}<0.3$ interpret the financial situation for which it is not possible to evaluate or predict further development. In the Springate model, for $\mathrm{SM}<0.862$, problems can be expected in the enterprise. The benefit of the Taffler model lies in the possibility of external diagnostic analysis based on the financial statements. The limitation of the Taffler model and the Springate model is that they do not take into account the sectoral and regional specificities of the operation of economic subjects. The weights of the indicators are determined on the basis of statistics, which express dynamics of the development of enterprises under conditions that are significantly different from those of Slovak enterprises.

The creditworthy model Aspect Global Rating (AGR) is an additive sum of seven ratios: return on sales measured using EBITDA, return on equity, basic earning power, total assets turnover ratio, coverage of depreciation, current ratio, financial autonomy. Rating has 9 degrees, namely (Kubickova \& Jindrichovska, 2015): AAA - an optimal managed business entity approaching an ideal business; AA - a very good managed business entity with strong financial health; A - a stable and financially healthy business entity with minimum reserves in profitability or liquidity; $\mathrm{BBB}$ - a stable and mediocre managed business entity; $\mathrm{BB}$ - a mediocre managed business entity; $\mathrm{B}-\mathrm{a}$ business entity with clear reserves and issues that need to be very well tracked; CCC - a under-moderate managed business entity, whose profitability and liquidity require recovery; CC - a financially unhealthy business entity with short-term and long-term problems; $\mathrm{C}$ - a business entity on the brink of bankruptcy with considerable risks and frequent crises.

\section{RESULTS AND DISCUSSION}

Based on the results of the bankruptcy models, we divided the analyzed corporations into appropriate intervals, with the exact number in each considered interval for the Taffler model and Springate model shown in Table 2, with percentages in Table 3. In the analysis of the Taffler model for 2012, 18 companies were not included; for 2013, 3 companies were not included; for 2014, 2 companies were not included; and for 2016, one company was not included. In 2012, there were 10 companies within the Zt $<0.2$ range, specifically, Siix Ems Slovakia, s.r.o., Nitra; Elektronika Slovensko, a.s. (in 2016 with the business name Robertshaw); Air Liquide Welding 
Central Europe, s.r.o.; VUKI, a.s., Bratislava; Neways Slovakia, a.s., Nová Dubnica; VEM Slovakia, s.r.o., Piešt’any; ZVT-Print, a.s., Banská Bystrica; Elvin, s.r.o., Rabča; Kiwa, s.r.o., Nitra (in 2017 in restructuring); OVP Orava, s.r.o., Trstená.

According to the Springate model, based on our results, in 2012, 39 companies acquired values below the mentioned limit (0.862); in 2016, the result was 42 companies.

Tab. 2 - Number of non-financial corporations included in the intervals applicable for the Taffler model and Springate model. Source: own research

\begin{tabular}{|l|l|l|l|l|l|}
\hline Interval Zt, SM & 2012 & 2013 & 2014 & 2015 & 2016 \\
\hline $\mathrm{Zt}>0.3$ & 106 & 120 & 125 & 121 & 115 \\
\hline $0.2<\mathrm{Zt}<0.3$ & 4 & 6 & 3 & 7 & 8 \\
\hline $\mathrm{Zt}<0.2$ & 10 & 9 & 8 & 10 & 14 \\
\hline $\mathrm{SM} \geq 0.862$ & 81 & 95 & 95 & 96 & 96 \\
\hline $\mathrm{SM}<0.862$ & 39 & 41 & 42 & 42 & 42 \\
\hline
\end{tabular}

Tab. 3 - Number of non-financial corporations (in percentage) included in the intervals applicable for the Taffler model and Springate model. Source: own research

\begin{tabular}{|l|l|l|l|l|l|}
\hline Interval Zt, SM & 2012 & 2013 & 2014 & 2015 & 2016 \\
\hline Zt $>0.3$ & 88.33 & 88.88 & 91.91 & 87.68 & 83.94 \\
\hline $0.2<\mathrm{Zt}<0.3$ & 3.33 & 4.44 & 2.2 & 5.14 & 5.83 \\
\hline $\mathrm{Zt}<0.2$ & 8.33 & 6.66 & 5.88 & 7.53 & 10.21 \\
\hline $\mathrm{SM} \geq 0.862$ & 67.5 & 69.85 & 69.34 & 69.56 & 69.56 \\
\hline $\mathrm{SM}<0.862$ & 32.5 & 30.14 & 30.65 & 30.43 & 30.43 \\
\hline
\end{tabular}

According to the results of the AGR model, for the period 2012-2016 the number of non-financial corporations classified by a AGR rating is presented in Table 4, with the percentage shown in Figure 1. The largest number of corporations fell within the AAA group, indicating that the industry is financially healthy. Nevertheless, according to this model the number of entities on the brink of bankruptcy with significant risks and frequent crises was higher. In the analysis of the AGR model for 2016, Panasonic AVC Networks Slovakia, s.r.o., Krompachy was not included (the company moved production to the Czech Republic and changed the trend in modern technologies). In addition, for the period 2012-2015, Bizlink Technology, s.r.o. was also not included.

Tab. 4 - Number of non-financial corporations included in the intervals applicable for the Aspect Global Rating. Source: own research

\begin{tabular}{|l|l|l|l|l|l|l|}
\hline Rating & Index AGR & 2012 & 2013 & 2014 & 2015 & 2016 \\
\hline AAA & $8.5<$ AGR & 28 & 36 & 45 & 37 & 36 \\
\hline AA & $7 \leq$ AGR $<8.5$ & 11 & 12 & 18 & 16 & 13 \\
\hline A & $5.75 \leq$ AGR $<7$ & 15 & 19 & 14 & 16 & 15 \\
\hline BBB & $4.75 \leq$ AGR $<5.75$ & 19 & 19 & 14 & 23 & 16 \\
\hline
\end{tabular}




\begin{tabular}{|l|l|l|l|l|l|l|}
\hline BB & $4 \leq$ AGR $<4.75$ & 11 & 17 & 14 & 11 & 17 \\
\hline B & $3.25 \leq$ AGR $<4$ & 13 & 10 & 13 & 12 & 18 \\
\hline CCC & $2.5 \leq$ AGR $<3.25$ & 9 & 12 & 9 & 9 & 6 \\
\hline CC & $1.5 \leq$ AGR $<2.5$ & 3 & 3 & 2 & 5 & 5 \\
\hline C & AGR $<1.5$ & 5 & 8 & 8 & 8 & 11 \\
\hline
\end{tabular}

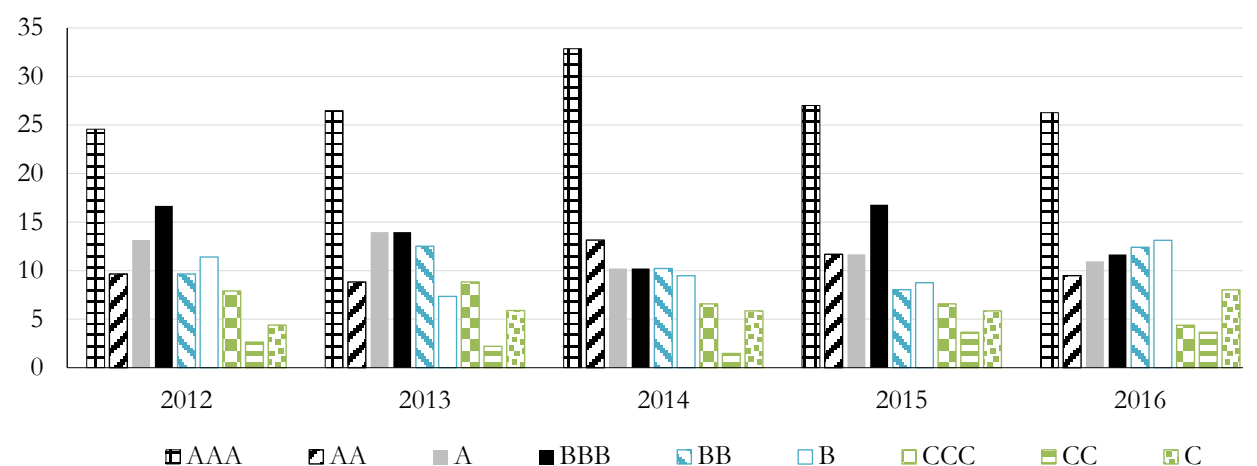

Fig. 1 - Number of non-financial corporations (in \%) included in the intervals applicable for Aspect Global Rating. Source: own research

The calculated values of the used models for each of the 138 non-financial corporations of the electrical engineering industry are presented in Table 5. (see Appendix I.).

Based on the results of a multidimensional discriminatory analysis by applying the Taffler bankruptcy model, we can say that the non-financial corporations of the Slovak electrical engineering industry are prosperous. According to the Springate model, $27.53 \%$ of companies could have expected problems in the last two years. According to the Aspect Global Rating, the most frequent rating was AAA (for $26.27 \%$ of all enterprises) as an optimally managed business entity approaching an ideal business, with $8.02 \%$ of all enterprises on the brink of bankruptcy.

The presented results are the starting point for a further elaboration on the models as well as the basis for further discussion. For further research (e.g., to create a logistic model), it is necessary to take into account qualitative variables, e.g., a region-related variable or the size of a company, as company size is an important factor in predicting the failure of new companies. Small businesses have a higher tendency toward bankruptcy than do large companies. On the other hand, for large companies, a lower failure rate can be presumed, as due to their size they can carry out more extensive transactions under more favorable conditions and so on. For an overall assessment of the electrical engineering industry, it would be beneficial to complement the follow-up research with a cluster analysis aimed at grouping companies based on economic efficiency indicators. It is necessary to map the production potential of Slovak electrical engineering companies to create a database of all non-financial corporations and to support these results with those from subcontractors in other fields of industrial production (e.g. automotive, engineering). An optimal level 
of investment in this industry is required, as the current rate of investment is currently insufficient to sustain the development trend is needed to strengthen competitiveness.

\section{CONCLUSION}

Financial aspects are key factors in the process of company's development (Stefko et al., 2016). Knowledge regarding the company's financial health can help the company thrive in a highly competitive market. Atiya (2001) has pointed out that negative earnings may indicate that company is losing its competitiveness. Forecasting methods concerned with the financial situation of individual non-financial corporations can provide insights into their financial health.

As the Slovak Republic has a poorly developed capital market and a large number of private companies do not have publicly traded securities, in this paper we used models based on information from financial statements, the use of which is preferable than that of market-oriented models. We determined the financial situation of 138 non-financial corporations in the Slovak electrical engineering industry using the Taffler model and Springare model as bankruptcy models, with the Aspect Global Rating as a creditworthy model. In addition, as the electrical engineering industry is one of the largest industries in the world, we briefly described the Slovak electrical engineering industry as an overall sector of economy. The results of the Taffler model evidenced that the nonfinancial corporations within the Slovak electrical engineering industry are prosperous. On the other hand, in the last two years, $27.53 \%$ of the analyzed companies could expect problems according to the Springate model. The Aspect Global Rating model showed that the most frequent credit rating was AAA (for $26.27 \%$ of all non-financial corporations), a finding which provides information about an optimally managed business entity approaching an ideal business, whereas $8.02 \%$ of all enterprises were on the brink of bankruptcy (rating C).

Comprehensive business evaluation methods have a degree of transparency, but at the same time are disadvantageous because of their inaccuracy. Therefore, financial analysts should use several predictive methods to assess and clarify the financial health of companies. Unlike Western companies, with Slovak firms it is necessary to use multiple methods to evaluate the company objectively, and to then compare the obtained results before predicting possible business developments. Any financial analyst can generate his/her own model to assess the financial situation of the business entity, but while taking into account the results of the financial and economic analysis, the financial manager should focus on a single aggregate indicator on the basis of which he/she might predict the situation of the company.

\section{Acknowledgements}

"This contribution was supported by research grant VEGA No. 1/0807/19. This work was supported by the Slovak Research and Development Agency under the contract no. APVV-17-0166."

\section{References}

1. Agostini, M. (2018). Corporate Financial Distress: Going Concern Evaluation in Both International and US Contexts. Switzerland: Springer.

2. Altman, E.I. (2000). Predicting Financial Distress of Companies. Revisiting the Z-score and Zeta Model. New York: Stern School of Business, New York University, 9-12. 
3. Arslan, N., \& Tathdil, H. (2012). Defining and measuring competitiveness: a comparative analysis of Turkey with 11 potential rivals. International Journal of Basic \& Applied Sciences, 12 (2), 31-43.

4. Atiya, A. F. (2001). Bankruptcy prediction for credit risk using neural networks: A survey and new results. IEEE Transactions on neural networks, 12 (4), 929-935.

5. Baran, D. (2006). Finančno-ekonomická analýza podniku v praxi. Bratislava: Iris.

6. Belas, J., \& Cipovova, E. (2011). Internal model of commercial bank as an instrument for measuring credit risk of the borrower in relation to financial performance (credit scoring and bankruptcy models). Journal of Competitiveness, 4, 104-120.

7. Benhayoun, N., Chairi, I., El Gonnouni, A., \& Lyhyaoui, A. (2013). Financial intelligence in prediction of firm's creditworthiness risk: evidence from support vector machine approach. Procedia Economics and Finance, 5 (1), 103-112.

8. Birchall, A. (2014). Financial analysis and control: financial awareness for students and managers. Oxford: Butterworth-Heinemann.

9. Bobinaite, V. (2015). Financial sustainability of wind electricity sectors in the Baltic States. Renewable and Sustainable Energy Reviews, 47 (1), 794-815.

10. Bondareva, I. (2011). Analysis of explanatory models of the predictive ability of the financial condition of the company in Slovakia. In Manažment podnikania a vecí verejných: Zborník vedeckých prác 2011, 59-64. Bratislava (Slovakia): SAM.

11. Bordeianu, G. D., Radu, F., Paraschivescu, M. D., \& Pavaloaia, W. (2011). Analysis models of the bankruptcy risk. Economy Transdisciplinarity Cognition, 14 (1), 248-259.

12. Chikán, A. (2008). National and firm competitiveness: a general research model. Competitiveness Review: An International Business Journal, 18 (1/2), 20-28.

13. Dobrovic, J., Lambovska, M., Gallo, P., \& Timkova, V. (2018). Non-financial indicators and their importance in small and medium-sized enterprises. Journal of Competitiveness, 10 (2), $41-55$.

14. El Khoury, R., \& Al Beaïno, R. (2014). Classifying manufacturing firms in Lebanon: An application of Altman's model. Procedia-Social and Behavioral Sciences, 109 (1), 11-18.

15. Eurostat database (2018). NACE Rev. 2 structure and correspondences with NACE Rev. 1.1 and ISIC Rev. 4. Retrieved December 6, 2018, from https://ec.europa.eu/eurostat/ documents/1965800/1978839/NACE_rev2_structure_EN.pdf/44414a11-15a7-4bf3-a5fcfc $4 \mathrm{~d} 1 \mathrm{dc} 5 \mathrm{a} 6 \mathrm{c} 1$

16. Fernández, E., Iglesias-Antelo, S., López-López, V., Rodríguez-Rey, M., \& FernandezJardon, C. M. (2019). Firm and industry effects on small, medium-sized and large firms' performance. BRQ Business Research Quarterly, 22 (1), 25-35.

17. Gundova, P. (2012). Využitie metód multikriteriálneho hodnotenia a neurónových sietí vo finančnom riadeni a rozhodovaní. In Zbornik prispevkov z medzinarodnej vedeckej konferencie pre doktorandov a mladych vedeckych pracovnikov MERKUR 2012, 1-16. Brartislava (Slovakia): Ekonóm. 
18. Harumova, A., \& Janisova, M. (2014). Hodnotenie slovenských podnikov pomocou skóringovej funkcie. Ekonomický časopis, 62 (5), 522-539.

19. Jakubik, P., \& Teply, P. (2011). The JT Index as an indicator of financial stability of corporate sector. Prague economic papers, 20 (2), 157-176.

20. Jencova, S. (2018). Aplikécia pokročilých metód vo finančno-ekonomickej analýze elektrotechnickébo odvetvia Slovenskej republiky. Ostrava: SAEI, VSB-TU Ostrava.

21. Jencova, S., Litavcova, E., \& Vasanicova, P. (2016). Implementation of financial and statistical models to study the Electrical industry of the Slovak. Republic. In 3rd International Multidisciplinary Scientific Conference on Social Sciences and Arts SGEM 2016, 329-336. Albena (Bulgaria).

22. Jencova, S., Litavcova, E., \& Vasanicova, P. (2018). Implementation of Du Pont Model in Non-Financial Corporations. Montenegrin Journal of Economics, 14 (2), 131-141.

23. Jencova, S., Litavcova, E., Vasanicova, P., \& Kosikova, M. (2017). Implementation of multidimensional analytic methods to compare performance between corporations. In R. Nemec, \& L. Chytilova (Ed.), Strategic management and its support by information systems, Proceedings of the 12th International Conference, SMSIS 2017, 21-29. Ostrava (Czech Republic): VSB Technical university of Ostrava.

24. Kabat, L., Sobekova Majkova, M., \& Vincurova, Z. (2013). Hodnotenie podniku a analýza jebo finančného zdravia. Bratislava: Iura Edition.

25. Kadarova, J., \& Turisova, R. (2011). Finančné modely predikcie finančných problémov v priemyselných podnikoch. In D. Tucek (Ed.), Modelovani, simulace a optimalizace podnikovych procesu v praxi: Sbornik z konference konané dne 29. března 2011,167-173. Praha (Czech Republic): ČSOP.

26. Kalouda, F. (2016). Finančni analyza a ř́zenípodniku. Plzen: Ales Cenek.

27. Kamenikova, K. (2005). Obmedzenia použitia modelov predikcie finančného vývoja podniku v podmienkach Slovenskej republiky. Acta Montanistica Slovaca, 10 (3), 337-343.

28. Kisel’áková, D., Šofranková, B., Čabinová, V., \& Šoltésová, J. (2018). Analysis of enterprise performance and competitiveness to streamline managerial decisions. Polish Journal of Management Studies, 17 (2), 101-111.

29. Kislingerova, E., \& Hnilica, J. (2005). Finančni analýza - krok za krokem. Praha: C. H. Beck.

30. Kliestik, T., Vrbka, J., \& Rowland, Z. (2018). Bankruptcy prediction in Visegrad group countries using multiple discriminant analysis. Equilibrium. Quarterly Journal of Economics and Economic Policy, 13 (3), 569-593.

31. Kralicek, P. (1993). Základy finančního hospodaření. Praha: Linde.

32. Kubickova, D., \& Jindrichovska, I. (2015). Finančni analýza a hodnoceni výkonnosti firmy. Praha: C. H. Beck.

33. Litavcova, E., Jencova, S., \& Vasanicova, P. (2017). On Modelling the Evolution of Financial Metrics in Decision Making Unit in the Electronics Industries. In P. Prazak (Ed.), MME 2017. 35th Inter-national Conference on Mathematical Methods in Economics, 408-413. Hradec Kralove (Czech Republic): University of Hradec Kralove. 
34. López Salazar, A., Contreras Soto, R., \& Espinosa Mosqueda, R. (2012). The impact of financial decisions and strategy on small business competitiveness. Global Journal of Business Research, 6 (2), 93-103.

35. Malega, P., \& Bjaloncikova, M. (2012). Analýza finančného zdravia spoločnosti. In R. Kotulic (Ed.), Zborník vedeckých prác katedry ekonómie a ekonomiky ANNO 2012, 171-183. Presov (Slovakia).

36. Neumaierova, I., \& Neumaier, I. (2005). Index IN05. In Evropske financni systemy: Sbornik prispevku z mezinárodni vedecke conference, 143-148. Brno (Czech Republic): Masarykova univerzita v Brne.

37. Ohlson, J. A. (1980). Financial ratios and probabilistic prediction of bankruptcy. Journal of Accouting Research, 18 (1), 109-131.

38. Pavaloaia, V. D., \& Strimbei, C. (2015). Experiments and results by modeling the financial domain with UML. Procedia Economics and Finance, 20 (1), 510-517.

39. Porter, M. E. (1980). Competitive Strategy: Techniques for Analyzing Industries and Competitors. New York: Free Press.

40. Rajnoha, R., Novak, P., \& Merkova, M. (2016). Relationships between Investment Effectiveness Controlling and Business Performance. Montenegrin Journal of Economics, 12 (2), $29-44$.

41. Reznakova, M., \& Karas, M. (2014). Bankruptcy Prediction Models: Can the prediction power of the models be improved by using dynamic indicators?. Procedia Economics and Finance, 12 (1), 565-574.

42. Rynik, J. (2018). Priemyselná scéna je fungujúce dedičstvo. Revue priemyslu, 10 (1), 38-44

43. Sikula, M., Gabrielova, H., Chovan, I., Klas, A., \& Kosta, J. (2003). Determinanty formovania priemyselnej politiky v podmienkach globalizácie a integrácie. Bratislava: Ústav slovenskej a svetovej ekonomiky SAV.

44. Slavicek, O., \& Kubenka, M. (2016). Bankruptcy prediction models based on the logistic regression for companies in the Czech Republic. In 8th International Scientific Conference Managing and Modelling of Financial Risks, 924-931. Ostrava (Czech Republic): VSB-TU of Ostrava.

45. Stefko, R., Gavurova, B., \& Korony, S. (2016). Efficiency measurement in healthcare work management using Malmquist indices. Polish Journal of Management Studies, 13 (1), 168-180.

46. Valaskova, K., Kliestik, T., Svabova, L., \& Adamko, P. (2018). Financial risk measurement and prediction modelling for sustainable development of business entities using regression analysis. Sustainability, 10 (7), 2144.

47. Valecky, J., \& Slivkova, E. (2012). Mikroekonomický scoringový model úpadku českých podniků. Ekonomicka revue ER-CEREI, 15 (1), 15-26.

48. Vernimmen, P., Quiry, P., Dallocchio, M., Le Fur, Y., \& Salvi, A. (2014). Corporate finance: theory and practice. UK: John Wiley \& Sons.

49. Vlachvei, A., Notta, O., Karantininis, K., \& Tsounis, N. (Eds.). (2016). Factors affecting firm competitiveness and performance in the modern business world. USA: IGI Global. 
50. Vochozka, M. (2011). Metody komplexního bodnoceni podniku. Praha: Grada Publishing.

51. Yuan-Qiang, L. (2018). TS fuzzy prediction on competitive structure model and evaluation system of emerging industry innovation alliance. Cognitive Systems Research, 52 (1), 192-197.

\section{Contact information}

prof. Ing. Robert Stefko, Ph.D.

University of Prešov

Faculty of Management

Department of Marketing and International Trade

Slovakia

E-mail:robert.stefko@unipo.sk

ORCID: 0000-0002-0650-7780

doc. Ing. Sylvia Jencova, PhD.

University of Prešov

Faculty of Management

Department of Finance

Slovakia

E-mail:sylvia.jencova@unipo.sk

ORCID: 0000-0002-0736-0880

Mgr. Petra Vasanicova, PhD.

University of Prešov

Faculty of Management

Department of Mathematical Methods and Managerial Informatics

Slovakia

E-mail:petra.vasanicova@gmail.com

ORCID: 0000-0001-7353-2057

doc. Mgr. Eva Litavcova, PhD.

University of Prešov

Faculty of Management

Department of Mathematical Methods and Managerial Informatics

Slovakia

E-mail:eva.litavcova@unipo.sk

ORCID: 0000-0002-5323-4359 


\section{Appendix I.}

Tab. 5 - Values of models for individual corporations. Source: own research

\begin{tabular}{|c|c|c|c|c|c|c|c|c|c|c|c|c|c|c|c|c|}
\hline \multirow{2}{*}{ Id. } & \multirow{2}{*}{$\begin{array}{l}\text { Electrical enginee- } \\
\text { ring non-financial cor- } \\
\text { porations }\end{array}$} & \multicolumn{5}{|c|}{ Taffler model } & \multicolumn{5}{|c|}{ Springate model } & \multicolumn{5}{|c|}{ Aspect Global Rating } \\
\hline & & 2012 & 2013 & 2014 & 2015 & 2016 & 2012 & 2013 & 2014 & 2015 & 2016 & 2012 & 2013 & 2014 & 2015 & 2016 \\
\hline 1 & $\begin{array}{l}\text { Samsung Electronics } \\
\text { Slovakia }\end{array}$ & 1.24 & 1.41 & 1.17 & 1.17 & 1.1 & 2.65 & 2.57 & 2.24 & 2.16 & 2.07 & AAA & AAA & AAA & AAA & AAA \\
\hline 2 & Foxconn Slovakia & 0.53 & 0.55 & 0.66 & 0.63 & 0.67 & 1.46 & 1.07 & 1.02 & 1.5 & 1.73 & BBB & BB & BB & $\mathrm{AA}$ & $\mathrm{AA}$ \\
\hline 3 & ZKW Slovakia & 0.37 & 0.52 & 0.54 & 0.43 & 0.57 & 0.49 & 1 & 1.11 & 0.66 & 1.08 & B & A & A & B & BBB \\
\hline 4 & Whirlpool Slovakia & 0.54 & 0.56 & 0.62 & 0.69 & 0.59 & 0.83 & 0.72 & 0.86 & 0.86 & 0.54 & BBB & BBB & $\mathrm{AA}$ & $\mathrm{AA}$ & BB \\
\hline 5 & $\begin{array}{l}\text { TRW Automotive (Slo- } \\
\text { vakia) }\end{array}$ & 0.56 & 0.65 & 0.79 & 0.77 & 1.15 & -0.21 & 0.14 & 0.7 & 1.3 & 3.08 & C & $\mathrm{CCC}$ & BB & BBB & AAA \\
\hline 6 & $\begin{array}{l}\text { Universal Media Cor- } \\
\text { poration }\end{array}$ & 0.53 & 0.59 & 0.61 & 0.42 & 0.58 & 1.73 & 1.43 & 1.54 & 1.28 & 1.67 & & BB & AA & AAA & $\mathrm{CC}$ \\
\hline 7 & $\begin{array}{l}\text { Visteon Electronics } \\
\text { Slovakia } \\
\end{array}$ & & & 0.46 & 0.7 & 0.68 & & & 0.76 & 1.11 & 1.71 & & & $\mathrm{CC}$ & BB & A \\
\hline 8 & $\begin{array}{l}\text { Hella Slovakia Sig- } \\
\text { nal-Lighting }\end{array}$ & 0.38 & 0.38 & 0.34 & 0.38 & 0.37 & 0.82 & 0.69 & 0.59 & 0.39 & 0.34 & B & B & B & B & B \\
\hline 9 & $\begin{array}{l}\text { Panasonic Industrial } \\
\text { Devices Slovakia }\end{array}$ & 0.65 & 0.79 & 0.91 & 0.86 & 1.1 & 1.27 & 1.9 & 2.28 & 2.15 & 2.89 & BB & A & AA & A & AAA \\
\hline 10 & Datalogic Slovakia & 0.56 & 0.52 & 0.79 & 0.72 & 0.64 & 1.27 & 1.08 & 2.23 & 1.61 & 1.15 & AAA & $\mathrm{AAA}$ & AAA & AAA & AAA \\
\hline 11 & BSH Drives and Pumps & 0.72 & 0.79 & 0.77 & 0.72 & 0.69 & 1.84 & 1.82 & 1.69 & 1.46 & 1.43 & A & $\mathrm{AA}$ & A & A & A \\
\hline 12 & $\begin{array}{l}\text { Hella Slovakia Front- } \\
\text { Lighting }\end{array}$ & 2.11 & 0.71 & 0.69 & 0.61 & 0.47 & 3.77 & 1.65 & 1.6 & 1.31 & 0.78 & & $\mathrm{AA}$ & A & BBB & B \\
\hline 13 & $\begin{array}{l}\text { Vertiv Slovakia (Emer- } \\
\text { son, a.s.) }\end{array}$ & 0.62 & 0.54 & 0.6 & 0.53 & 0.7 & 1.32 & 1.08 & 1.16 & 0.98 & 1.39 & $\mathrm{AA}$ & A & AA & AA & AAA \\
\hline 14 & Leoni Slovakia & 0.49 & 0.6 & 0.61 & 0.75 & 0.44 & 0.85 & 1.27 & 1.25 & 1.24 & 0.61 & BB & BBB & A & BBB & BB \\
\hline 15 & Osram & 1 & 0.73 & 0.81 & 0.91 & 1.08 & 2.39 & 1.81 & 2.12 & 2.29 & 2.7 & $\mathrm{AA}$ & $\mathrm{AA}$ & A & $\mathrm{AA}$ & AAA \\
\hline 16 & Elster & 0.86 & 0.5 & 1.05 & 1.31 & 0.8 & 2.19 & 0.58 & 2.56 & 3.22 & 1.86 & $\mathrm{AA}$ & $\mathrm{CC}$ & AAA & $\mathrm{AAA}$ & AA \\
\hline 17 & Semikron & 0.7 & 0.92 & 0.92 & 0.85 & 0.79 & 1.42 & 2.22 & 2.2 & 1.88 & 1.68 & A & $\mathrm{AA}$ & $\mathrm{AA}$ & A & A \\
\hline 18 & $\begin{array}{l}\text { Shin Heung Precision } \\
\text { Slovakia }\end{array}$ & 0.77 & 0.37 & 0.7 & 0.66 & 0.55 & 1.87 & 0.69 & 1.68 & 1.55 & 1.18 & A & B & AA & BBB & BBB \\
\hline 19 & Topaz LGP & 0.87 & 1.06 & 1.11 & 1.04 & 0.82 & 1.61 & 2.02 & 2.17 & 1.58 & 1 & $\mathrm{AA}$ & A & AAA & A & BB \\
\hline 20 & $\begin{array}{l}\text { KraussMaffei Tech- } \\
\text { nologies }\end{array}$ & 0.6 & 0.36 & 0.68 & 0.67 & 0.68 & 0.87 & 0.23 & 1.09 & 0.96 & 1.26 & & C & BB & $\mathrm{CCC}$ & BB \\
\hline 21 & Enics Slovakia & 0.88 & 0.81 & 1.08 & 0.75 & 0.8 & 1.95 & 1.87 & 3.09 & 1.79 & 1.78 & BBB & A & AAA & BBB & A \\
\hline 22 & Delta Electronics & 0.5 & 0.59 & 0.93 & 0.8 & 0.67 & 1.15 & 1.29 & 1.83 & 1.41 & 1.09 & BBB & $\mathrm{AA}$ & AAA & $\mathrm{AA}$ & $\mathrm{AA}$ \\
\hline 23 & Seong Ji Slovakia & 1.29 & 1.19 & 1.1 & 1.07 & 1.11 & 2.95 & 2.59 & 2.52 & 2.26 & 2.65 & AAA & $\mathrm{AA}$ & AAA & $\mathrm{AA}$ & B \\
\hline 24 & Eltek & 0.49 & 0.54 & 0.61 & 0.61 & 0.48 & 1.27 & 1.3 & 1.4 & 1.36 & 0.67 & BBB & BBB & A & BBB & B \\
\hline 25 & $\begin{array}{l}\text { Samsung Display Slo- } \\
\text { vakia }\end{array}$ & 0.8 & 0.54 & 0.42 & 0.36 & 0.46 & 1.5 & 0.82 & 0.6 & 0.56 & 0.71 & BB & $\mathrm{CCC}$ & CCC & B & $\mathrm{CCC}$ \\
\hline 26 & PPA Energo & 0.59 & 0.66 & 0.83 & 0.76 & 0.72 & 1.26 & 1.67 & 2.26 & 2.02 & 1.91 & AAA & AAA & AAA & AAA & AAA \\
\hline 27 & Dometic Slovakia & 0.37 & 0.48 & 0.65 & 0.85 & 1.02 & 0.82 & 0.73 & 1.47 & 2.02 & 2.55 & BBB & BB & BBB & BB & AAA \\
\hline 28 & PPA Controll & 0.56 & 0.5 & 0.54 & 0.56 & 0.5 & 0.81 & 0.73 & 1.01 & 1.01 & 0.8 & A & AAA & AAA & AAA & AAA \\
\hline 29 & OMS & 0.38 & 0.38 & 0.17 & 0.34 & 0.27 & 0.95 & 0.94 & 0.21 & 0.71 & 0.59 & B & BB & C & $\mathrm{CCC}$ & C \\
\hline 30 & Vicente Torns Slovakia & 0.49 & 0.49 & 0.5 & 0.51 & 0.42 & 1.21 & 1.22 & 1.2 & 1.13 & 0.9 & BBB & BBB & BBB & BB & B \\
\hline 31 & Askoll Slovakia & 0.56 & 0.59 & 0.55 & 0.43 & 0.16 & 1.28 & 1.31 & 1.19 & 0.83 & 0.14 & A & BBB & BBB & BB & B \\
\hline 32 & Siix Ems Slovakia & -0.53 & -0.14 & 0.43 & 0.41 & 0.64 & -1.92 & -0.78 & 0.88 & 1.02 & 1.77 & $\mathrm{C}$ & C & BB & BB & A \\
\hline 33 & Draka Comteq Slovakia & 0.78 & 0.82 & 0.91 & 0.5 & 0.43 & 1.71 & 1.91 & 2.24 & 0.68 & 0.34 & A & $\mathrm{AA}$ & $\mathrm{AA}$ & A & B \\
\hline 34 & Bizlink Technologi & & & & 0.16 & 0.32 & & & & -0.09 & 0.24 & & & & & $\mathrm{CC}$ \\
\hline 35 & $\mathrm{ABB}$ & 0.8 & 0.78 & 0.89 & 0.89 & 0.84 & 2.11 & 2.04 & 2.41 & 2.42 & 2.29 & AAA & AAA & AAA & AAA & AAA \\
\hline 36 & Bel Power Solutions & 0.53 & 0.64 & 0.58 & 0.6 & 0.52 & 0.78 & 1.26 & 1.00 & 1.15 & 1.37 & CCC & BBB & B & BBB & BB \\
\hline 37 & $\begin{array}{l}\text { ALCATEL-LUCENT } \\
\text { SLOVAKIA }\end{array}$ & 0.53 & 0.55 & 0.6 & 0.56 & 0.64 & 1.16 & 1.2 & 1.36 & 1.23 & 1.4 & BBB & A & A & A & $\mathrm{AA}$ \\
\hline 38 & $\begin{array}{l}\text { Robertshaw (Elektroni- } \\
\text { ka Slovensko) }\end{array}$ & -0.51 & 0.5 & 0.5 & 0.21 & 0.3 & $\mid-0.2$ & $|-0.1|$ & -0.47 & 0.24 & 0.46 & BBB & CCC & C & $\mathrm{CC}$ & C \\
\hline 39 & $\begin{array}{l}\text { Enpay Transformer } \\
\text { Components }\end{array}$ & 0.89 & 0.57 & 0.37 & 0.36 & 0.45 & 1.93 & 1.29 & 0.5 & 0.69 & 1.2 & $\mathrm{AA}$ & A & B & CCC & BB \\
\hline 40 & $\begin{array}{l}\text { Bauer Gear Motor Slo- } \\
\text { vakia }\end{array}$ & 0.36 & 0.4 & 0.52 & 0.55 & 0.52 & 0.97 & 1.1 & 1.32 & 1.32 & 1.31 & B & BB & BB & BB & BB \\
\hline 41 & $\begin{array}{l}\text { Air Liquide Welding } \\
\text { Central Europe }\end{array}$ & 0.16 & 0.28 & 0.34 & 0.49 & 0.46 & 0.48 & 0.74 & 0.75 & 1.1 & 0.85 & $\mathrm{CC}$ & $\mathrm{CCC}$ & CCC & BB & B \\
\hline
\end{tabular}




\begin{tabular}{|c|c|c|c|c|c|c|c|c|c|c|c|c|c|c|c|c|}
\hline 42 & $\begin{array}{l}\text { Schneider Electric } \\
\text { Slovakia }\end{array}$ & 0.73 & 0.58 & 0.64 & 0.78 & 0.79 & 1.48 & 0.76 & 0.9 & 1.8 & 1.92 & $\mathrm{AA}$ & $\mathrm{C}$ & $\mathrm{C}$ & $\mathrm{AAA}$ & $\mathrm{AAA}$ \\
\hline 43 & Honeywell & 0.79 & 0.93 & 0.81 & 0.81 & 0.61 & 1.66 & 1.79 & 1.63 & 1.54 & 1.23 & $\mathrm{AAA}$ & $\mathrm{AAA}$ & $\mathrm{AAA}$ & $\mathrm{AAA}$ & AAA \\
\hline 44 & Nuritech SK & 1.12 & 1.12 & 1.02 & 0.95 & 0.95 & 2.48 & 2.43 & 2.29 & 1.84 & 2.02 & $\mathrm{AAA}$ & $\mathrm{AAA}$ & $\mathrm{AA}$ & A & A \\
\hline 45 & EVPÚ & 0.46 & 0.51 & 0.46 & 0.54 & 0.6 & 0.97 & 0.99 & 0.91 & 1.1 & 1.12 & $\mathrm{BB}$ & $\mathrm{BB}$ & BBB & BBB & BBB \\
\hline 46 & Hydac Electronic & 1.51 & 1.26 & 1.99 & 2.2 & 2.27 & 2.57 & 2.22 & 2.97 & 3.15 & 3.33 & $\mathrm{AA}$ & A & $\mathrm{AA}$ & $\mathrm{AA}$ & AAA \\
\hline 47 & Tesla Stropkov & 1 & 1.05 & 1.14 & 0.87 & 0.74 & 1.7 & 1.71 & 1.87 & 1.59 & 1.39 & A & $\mathrm{AA}$ & AA & A & BBB \\
\hline 48 & Sensus Slovensko & & 0.89 & 0.93 & 0.83 & 0.67 & & 2.33 & 2.38 & 2.01 & 1.49 & & $\mathrm{AAA}$ & $\mathrm{AAA}$ & $\mathrm{AAA}$ & $\mathrm{AA}$ \\
\hline 49 & Danfoss & 0.9 & 1.13 & 1.38 & 1.68 & 1.64 & 1.63 & 1.86 & 1.76 & 1.83 & 1.72 & $\mathrm{AAA}$ & $\mathrm{AAA}$ & $\mathrm{AAA}$ & $\mathrm{AAA}$ & $\mathrm{AAA}$ \\
\hline 50 & Klauke Slovakia & 0.67 & 1.82 & 0.77 & 0.85 & 0.95 & 1.59 & 1.21 & 1.71 & 1.82 & 1.98 & A & A & $\mathrm{A}$ & $\mathrm{AA}$ & $\mathrm{AA}$ \\
\hline 51 & BEZ Transformátory & 0.35 & 0.24 & 0.2 & 0.23 & 0.19 & 0.65 & 0.51 & 0.35 & 0.38 & 0.35 & $\mathrm{CCC}$ & $\mathrm{CCC}$ & $\mathrm{C}$ & $\mathrm{CC}$ & C \\
\hline 52 & Linak Slovakia & & 0.98 & 0.76 & 0.63 & 0.61 & & 2.59 & 1.93 & 1.64 & 1.59 & & $\mathrm{AAA}$ & $\mathrm{AA}$ & A & A \\
\hline 53 & $\begin{array}{l}\text { Tatramat-ohrieva- } \\
\text { če vody }\end{array}$ & 0.57 & 0.42 & 0.46 & 0.8 & 1.09 & 1.24 & 0.66 & 0.74 & 1.37 & 1.67 & BBB & B & B & BBB & BBB \\
\hline 54 & Vacuumschmelze & 0.93 & 0.66 & 0.86 & 0.7 & 0.6 & 1.38 & 1.15 & 1.44 & 1.26 & 1.08 & $\mathrm{AA}$ & A & $\mathrm{AA}$ & A & $\mathrm{A}$ \\
\hline 55 & Datamars Slovakia & 1.39 & 0.39 & 0.55 & 0.28 & 0.49 & -16.72 & 0.25 & 0.47 & 0.64 & 1.25 & C & $\mathrm{CCC}$ & $\mathrm{AAA}$ & $\mathrm{CCC}$ & $\mathrm{B}$ \\
\hline 56 & $\begin{array}{l}\text { ICS Industrial Cables } \\
\text { Slovakia }\end{array}$ & 0.28 & 0.29 & 0.46 & 0.52 & 0.49 & 0.7 & 0.7 & 1.11 & 1.28 & 1.14 & $\mathrm{CCC}$ & $\mathrm{CCC}$ & BB & BBB & BB \\
\hline 57 & Calearo Slovakia & & 0.58 & 0.59 & 0.9 & 0.7 & & 1.35 & 1.33 & 2.29 & 1.31 & & BBB & BBB & A & BBB \\
\hline 58 & BBF elektro & & 0.35 & 0.31 & 0.44 & 0.65 & & 0.74 & 0.62 & 1.03 & 1.66 & & BB & B & BBB & AAA \\
\hline 59 & Elba & 1.99 & 1.8 & 2.11 & 2.82 & 1.04 & 3.42 & 2.86 & 3.5 & 4.33 & 1.5 & AAA & $\mathrm{AAA}$ & $\mathrm{AAA}$ & $\mathrm{AAA}$ & $\mathrm{AA}$ \\
\hline 60 & AU Optronics & & 0.12 & 0.16 & 0.16 & 0.16 & & -0.43 & -0.47 & -0.44 & -0.36 & & $\mathrm{CC}$ & CCC & $\mathrm{CC}$ & $\mathrm{CC}$ \\
\hline 61 & Hengstler & 0.93 & 0.78 & 1 & 1.08 & 1.06 & 1.98 & 1.57 & 1.96 & 2 & 2.06 & A & A & $\mathrm{AA}$ & $\mathrm{AA}$ & $\mathrm{AA}$ \\
\hline 62 & PPA Inžiniering & 1.08 & 0.7 & 0.77 & 0.7 & 0.66 & 2.66 & 1.34 & 1.8 & 1.53 & 1.39 & $\mathrm{AAA}$ & BBB & $\mathrm{AAA}$ & $\mathrm{AAA}$ & BBB \\
\hline 63 & $\begin{array}{l}\text { SEZ Krompachy, a.s., } \\
\text { Krompachy }\end{array}$ & 0.28 & 0.24 & 0.23 & 0.21 & 0.02 & 0.56 & 0.46 & 0.45 & 0.45 & 0.02 & B & B & B & B & $\mathrm{CC}$ \\
\hline 64 & Sylex & 0.65 & 0.65 & 0.49 & 0.46 & 0.6 & 1.4 & 1.42 & 1.02 & 1.03 & 1.43 & A & A & A & A & $\mathrm{AA}$ \\
\hline 65 & SLK Elektro & 0.57 & 0.6 & 0.64 & 0.59 & 0.89 & 0.83 & 1.75 & 1.89 & 1.84 & 2.49 & $\mathrm{CC}$ & $\mathrm{AA}$ & $\mathrm{AAA}$ & $\mathrm{AA}$ & $\mathrm{AAA}$ \\
\hline 66 & ZTS-Kabel & 0.86 & -0.27 & 0.86 & 1.92 & 1.07 & 1.85 & -0.07 & 1.76 & 3.45 & 1.73 & $\mathrm{AAA}$ & $\mathrm{C}$ & $\mathrm{AAA}$ & $\mathrm{AAA}$ & AAA \\
\hline 67 & Elkond HHK & 0.44 & 0.44 & 0.55 & 0.64 & 0.63 & 1.17 & 1.19 & 1.41 & 1.52 & 1.53 & BBB & BBB & $\mathrm{A}$ & $\mathrm{AA}$ & $\mathrm{A}$ \\
\hline 68 & ETI ELB & 0.55 & 0.4 & 0.55 & 0.57 & 0.57 & 1.21 & 0.6 & 0.26 & 0.43 & 0.44 & $\mathrm{BB}$ & $\mathrm{C}$ & BBB & $\mathrm{CCC}$ & C \\
\hline 69 & Alison Slovakia & 0.81 & 0.51 & 0.35 & 0.56 & 1.13 & 2.14 & 0.97 & 0.45 & 1.08 & 2.91 & A & $\mathrm{B}$ & $\mathrm{C}$ & $\mathrm{AAA}$ & $\mathrm{AAA}$ \\
\hline 70 & NES Nová Dubnica & 0.56 & 0.78 & 0.87 & 0.61 & 0.91 & 1.23 & 1.58 & 1.95 & 1.19 & 2.01 & A & $\mathrm{AA}$ & $\mathrm{AAA}$ & BBB & $\mathrm{AAA}$ \\
\hline 71 & Elettromil Slovakia & 1.53 & 1.27 & 1.86 & 1.98 & 3.79 & 1.9 & 1.55 & 2.5 & 2.78 & 3.96 & AAA & $\mathrm{AAA}$ & $\mathrm{AAA}$ & $\mathrm{AAA}$ & AAA \\
\hline 72 & Thorma Výroba & & 0.62 & 0.54 & -0.24 & 0.34 & & 1.25 & 1.02 & 0.07 & 1.14 & & A & $\mathrm{BB}$ & $\mathrm{C}$ & BB \\
\hline 73 & Hansol Technics Europe & 0.93 & 1.24 & 0.91 & 0.94 & 0.56 & 1.99 & 3.18 & 1.87 & 2.26 & 0.9 & $\mathrm{AAA}$ & $\mathrm{AAA}$ & $\mathrm{AAA}$ & $\mathrm{AAA}$ & AAA \\
\hline 74 & SEC & & 1.2 & 1.28 & 1.69 & 1.16 & & 1.84 & 1.75 & 2.05 & 1.47 & & A & $\mathrm{AA}$ & $\mathrm{AAA}$ & $\mathrm{AA}$ \\
\hline 75 & Elmax Žilina & 0.57 & 1.66 & 0.58 & 0.6 & 0.63 & 1.12 & -3.72 & 1.43 & 1.49 & 1.45 & BB & BBB & BBB & BBB & BBB \\
\hline 76 & VUKI & 0.16 & 0.44 & 0.1 & 0.39 & 0.38 & 0.28 & 0.79 & 0.23 & 0.7 & 0.73 & B & $\mathrm{BB}$ & B & $\mathrm{BB}$ & B \\
\hline 77 & $\begin{array}{l}\text { SVI Slovakia (Seidel } \\
\text { Slovakia) }\end{array}$ & 0.94 & 0.95 & 0.87 & 0.96 & 0.55 & 2.46 & 2.46 & 2.24 & 2.47 & 1.4 & AAA & AAA & $\mathrm{AAA}$ & $\mathrm{AAA}$ & A \\
\hline 78 & ProCs & 0.61 & 0.51 & 0.65 & 0.48 & 0.51 & 1.42 & 1.13 & 1.58 & 0.83 & 0.92 & $\mathrm{AAA}$ & $\mathrm{AA}$ & $\mathrm{AAA}$ & $\mathrm{BB}$ & $\mathrm{BB}$ \\
\hline 79 & Scame-SK & 0.31 & 0.35 & 0.35 & 0.39 & 0.34 & 0.32 & 0.39 & 0.39 & 0.52 & 0.41 & $\mathrm{CCC}$ & $\mathrm{CCC}$ & B & B & B \\
\hline 80 & JJ Electronic & 4.48 & 1.67 & 7.34 & 7.6 & 10.97 & 8.2 & 4.42 & 11.7 & 12.36 & 16.98 & $\mathrm{AAA}$ & $\mathrm{AAA}$ & $\mathrm{AAA}$ & $\mathrm{AAA}$ & AAA \\
\hline 81 & Neways Slovakia & 0.13 & 0.64 & 0.32 & 0.66 & 0.57 & 0.43 & 1.37 & 0.74 & 1.37 & 1.2 & $\mathrm{BB}$ & BBB & BB & BBB & BBB \\
\hline 82 & $2 \mathrm{~J}$ & 1.58 & 1.05 & 1.46 & 1.23 & 1.15 & 3.24 & 2.55 & 2.87 & 2.4 & 2.44 & $\mathrm{AAA}$ & $\mathrm{AAA}$ & $\mathrm{AAA}$ & $\mathrm{AAA}$ & $\mathrm{AAA}$ \\
\hline 83 & Semecs & 0.35 & 0.4 & 0.49 & 0.53 & 0.22 & 0.76 & 0.92 & 1.13 & 1.21 & 0.55 & BBB & BBB & BBB & BBB & $\mathrm{BB}$ \\
\hline 84 & MicroStep-MIS & 1.77 & 0.97 & 1.64 & 0.82 & 0.64 & 3.64 & 2.06 & 2.98 & 2.06 & 1.58 & $\mathrm{AAA}$ & $\mathrm{AAA}$ & $\mathrm{AAA}$ & $\mathrm{AAA}$ & AAA \\
\hline 85 & Cable Connect Žilina & 0.55 & 0.49 & 0.45 & 0.46 & 0.52 & 1.53 & 1.48 & 1.35 & 1.41 & 1.72 & AAA & BBB & B & BB & BBB \\
\hline 86 & $\begin{array}{l}\text { SAT Systémy automati- } \\
\text { začnej techniky }\end{array}$ & 0.58 & 0.76 & 0.65 & 0.78 & 0.64 & 1.43 & 1.96 & 1.61 & 2.05 & 1.6 & AAA & AAA & $\mathrm{AAA}$ & $\mathrm{AAA}$ & $\mathrm{AAA}$ \\
\hline 87 & SEZ DK & 0.49 & 0.42 & 0.42 & 0.52 & 0.56 & 0.97 & 0.91 & 0.85 & 1.06 & 1.14 & BBB & BBB & BB & BBB & A \\
\hline 88 & Elcom & 0.61 & 0.65 & 1.07 & 1.68 & 0.87 & 0.2 & 1.23 & 1.94 & 2.22 & 1.05 & $\mathrm{BB}$ & A & $\mathrm{AAA}$ & $\mathrm{AAA}$ & BBB \\
\hline 89 & Ross & & 0.74 & 0.57 & 0.52 & 0.56 & & 2.08 & 1.54 & 1.38 & 1.5 & & $\mathrm{AAA}$ & A & BBB & BBB \\
\hline 90 & CRT - Electronic & 0.41 & 0.38 & 0.35 & 0.37 & 0.41 & 0.66 & 0.47 & 0.65 & 0.74 & 0.89 & $\mathrm{~B}$ & $\mathrm{CCC}$ & CCC & $\mathrm{CCC}$ & B \\
\hline 91 & $\mathrm{~A} 2 \mathrm{~B}$ & & 0.59 & 0.78 & 0.74 & 0.83 & & 1.01 & 2.1 & 1.89 & 2.2 & & $\mathrm{~B}$ & $\mathrm{AAA}$ & $\mathrm{AAA}$ & $\mathrm{AAA}$ \\
\hline 92 & Avex electronics & 0.4 & 0.11 & 0.04 & -0.27 & -0.09 & 0.59 & -0.16 & -0.09 & -0.56 & -0.08 & B & A & $\mathrm{CC}$ & $\mathrm{CC}$ & $\mathrm{CCC}$ \\
\hline 93 & GE Energy Slovakia & 0.95 & 1.02 & 0.82 & 0.96 & 1 & 1.88 & 2.1 & 1.86 & 1.69 & 1.53 & & $\mathrm{AA}$ & $\mathrm{AAA}$ & $\mathrm{AA}$ & A \\
\hline 94 & Regada & 0.36 & 0.36 & 0.41 & 0.34 & 0.29 & 0.94 & 0.84 & 0.95 & 0.8 & 0.72 & BBB & $\mathrm{BB}$ & $\mathrm{BB}$ & B & $\mathrm{B}$ \\
\hline 95 & Elektro-Haramia & 0.77 & 0.55 & 0.83 & 0.96 & 1.16 & 1.59 & 0.85 & 2.21 & 2.57 & 2.72 & A & $\mathrm{B}$ & $\mathrm{AAA}$ & AAA & $\mathrm{AAA}$ \\
\hline 96 & Hasma & 1.2 & 0.85 & 0.97 & 0.93 & 0.78 & 2.75 & 2.01 & 2.07 & 2.01 & 1.76 & AAA & $\mathrm{AAA}$ & $\mathrm{AAA}$ & $\mathrm{AA}$ & A \\
\hline 97 & Telegrafia & 0.28 & 0.4 & 0.38 & 0.62 & 0.69 & 0.6 & 1.02 & 0.86 & 1.54 & 1.47 & $\mathrm{CCC}$ & BBB & BBB & $\mathrm{AA}$ & BBB \\
\hline
\end{tabular}




\begin{tabular}{|c|c|c|c|c|c|c|c|c|c|c|c|c|c|c|c|c|}
\hline 98 & Leadec & & 0.95 & 0.96 & 1.14 & 0.45 & & 2.43 & 2.42 & 2.84 & 1.01 & & $\mathrm{AAA}$ & $\mathrm{AAA}$ & $\mathrm{AAA}$ & $\mathrm{AAA}$ \\
\hline 99 & TTS Martin & & 0.69 & 0.41 & 0.46 & 0.47 & & 1.46 & 1.08 & 1.09 & 1.14 & A & BB & $\mathrm{B}$ & & \\
\hline 100 & HМH & 6.39 & 5.87 & 4.25 & 9.26 & 6.21 & 8.95 & 7.48 & 7.05 & 11.74 & 6.62 & $\mathrm{AAA}$ & AAA & $\mathrm{AAA}$ & $\mathrm{AAA}$ & $\mathrm{AAA}$ \\
\hline 101 & Elnec & 6.32 & 6.67 & 2.92 & 3.1 & 6.08 & 7.39 & 7.18 & 3.81 & 4.04 & 7.03 & AAA & AAA & $\mathrm{AAA}$ & $\mathrm{AAA}$ & $\mathrm{AAA}$ \\
\hline 102 & Emtest & 0.35 & -0.02 & 0.33 & 0.41 & 0.48 & 0.49 & -2.08 & 0.63 & 0.8 & 0.63 & $\mathrm{CCC}$ & C & $\mathrm{CCC}$ & $\mathrm{CCC}$ & $\mathrm{CCC}$ \\
\hline 103 & Delipro & 0.99 & 0.98 & 2.03 & 0.71 & 0.64 & 2.65 & 2.59 & 4.33 & 1.44 & 1 & AAA & $\mathrm{AAA}$ & $\mathrm{AAA}$ & $\mathrm{AA}$ & BB \\
\hline 104 & Orgeco & 0.41 & 0.46 & 0.36 & 0.34 & 0.47 & 0.98 & 1.15 & 0.94 & 0.85 & 1.12 & BB & BB & $\mathrm{BB}$ & B & $\mathrm{BB}$ \\
\hline 105 & Elektrokarbon & 0.43 & 0.15 & 0.07 & -0.03 & 0.29 & 0.81 & 0.33 & -0.17 & 0.17 & 0.77 & $\mathrm{~B}$ & $\mathrm{CC}$ & $\mathrm{C}$ & $\mathrm{C}$ & $\mathrm{B}$ \\
\hline 106 & MicroStep - HDO & 0.82 & 1.34 & 0.75 & 0.55 & 1.05 & 1.83 & 3.52 & 1.89 & 1.43 & 2.28 & AAA & AAA & $\mathrm{AAA}$ & $\mathrm{AAA}$ & AAA \\
\hline 107 & $\begin{array}{l}\text { MK Illumination pro- } \\
\text { duction }\end{array}$ & & 1.27 & 0.77 & 0.74 & 0.57 & & 3.1 & 1.77 & 1.68 & 1.39 & & AAA & A & A & A \\
\hline 108 & Regotrans - Rittmeyer & 0.43 & 0.47 & 0.58 & 0.58 & 0.57 & 0.6 & 1.11 & 1 & 1 & 1.08 & $\mathrm{C}$ & $\mathrm{AAA}$ & $\mathrm{AAA}$ & $\mathrm{A}$ & A \\
\hline 109 & Alcor - Signs & 1.82 & 0.76 & 0.84 & 1 & 0.92 & 2.84 & 1.97 & 2.23 & 2.5 & 2.27 & AAA & $\mathrm{AAA}$ & AAA & $\mathrm{AAA}$ & AAA \\
\hline 110 & Elteco & 0.39 & 0.41 & 0.28 & 0.16 & 0.12 & 1.13 & 1.07 & 0.83 & 0.1 & -0.31 & BBB & BBB & $\mathrm{CCC}$ & $\mathrm{C}$ & $\mathrm{C}$ \\
\hline 111 & Wire technologies & 0.97 & 0.83 & 0.56 & 0.64 & 1.19 & 2.16 & 1.89 & 1.43 & 1.57 & 2.42 & $\mathrm{AA}$ & A & BBB & BBB & $\mathrm{AAA}$ \\
\hline 112 & VEM Slovakia & -0.07 & 0.29 & 0.35 & 0.27 & 0.38 & -0.18 & 0.53 & 0.73 & 0.53 & 0.78 & $\mathrm{CC}$ & B & $\mathrm{BB}$ & B & $\mathrm{BB}$ \\
\hline 113 & Eldur Slovakia & 0.35 & 0.34 & 0.29 & 0.24 & 0.29 & 0.29 & 0.27 & 0.02 & -0.33 & -0.09 & BB & B & $\mathrm{CCC}$ & $\mathrm{CC}$ & $\mathrm{CC}$ \\
\hline 114 & $\mathrm{Am}$ & & 0.39 & 0.43 & 0.36 & 0.34 & & 0.73 & 0.89 & 0.73 & 0.69 & & B & B & B & $\mathrm{CCC}$ \\
\hline 115 & Altron SK & & 1.16 & 0.91 & 0.96 & 0.93 & & 2.49 & 1.95 & 2.34 & 2.22 & & $\mathrm{AAA}$ & $\mathrm{AAA}$ & $\mathrm{AAA}$ & $\mathrm{AA}$ \\
\hline 116 & Neonex & 0.25 & 0.2 & 0.32 & 0.33 & 0.35 & 0.34 & -0.18 & 0.63 & 0.7 & 0.92 & CCC & C & CCC & CCC & B \\
\hline 117 & Vinuta & 0.47 & 0.52 & 0.45 & 0.4 & 0.44 & 0.76 & 0.95 & 0.74 & 0.64 & 0.72 & $\mathrm{CCC}$ & BB & B & $\mathrm{CCC}$ & $\mathrm{CCC}$ \\
\hline 118 & $\begin{array}{l}\text { Hanton-svetelné re- } \\
\text { klamy }\end{array}$ & 0.32 & 0.33 & 0.34 & 0.28 & 0.41 & 0.85 & 0.92 & 0.91 & 0.72 & 1.09 & BBB & BB & BBB & B & $\mathrm{BB}$ \\
\hline 119 & $\begin{array}{l}\text { Montáže Čakovice Bra- } \\
\text { tislava }\end{array}$ & 1.17 & 1.01 & 0.84 & 0.54 & 1.13 & 2.85 & 2.47 & 1.99 & 1.04 & 2.45 & AAA & AAA & AAA & A & AAA \\
\hline 120 & Manomer SK & 1.07 & 0.59 & 0.65 & 0.41 & -0.04 & 1.06 & 0.29 & 0.73 & 0.61 & -0.25 & A & BBB & BB & BBB & $\mathrm{BB}$ \\
\hline 121 & $3 \mathrm{D}-$ Dianiška & & 0.48 & 0.5 & 0.46 & 0.31 & & 1.04 & 1.12 & 1.02 & 0.62 & & A & BBB & BBB & B \\
\hline 122 & Robotic SK & 1.43 & 0.77 & 0.66 & 1.31 & 1.47 & 4.12 & 2.13 & 1.56 & 4.02 & 3.97 & AAA & $\mathrm{AAA}$ & $\mathrm{AA}$ & $\mathrm{AAA}$ & $\mathrm{AAA}$ \\
\hline 123 & ZVT- Print & 0.17 & 0.24 & 0.31 & 0.36 & 0.29 & 0.56 & 0.69 & 0.8 & 0.76 & 0.73 & B & BB & $\mathrm{BB}$ & B & B \\
\hline 124 & EVPÚ PRO & 1.2 & 0.8 & 0.74 & 1.99 & 1 & 1.99 & 1.13 & 0.66 & 2.99 & 1.24 & $\mathrm{AA}$ & A & $\mathrm{AA}$ & $\mathrm{AAA}$ & $\mathrm{AA}$ \\
\hline 125 & Prematlak & & 0.56 & 0.31 & 0.4 & -0.17 & & 1.55 & 0.6 & 0.98 & -0.25 & & BBB & $\mathrm{CCC}$ & B & $\mathrm{C}$ \\
\hline 126 & RMC & 0.34 & 0.45 & 0.55 & 0.58 & 0.57 & 0.89 & 1.16 & 1.48 & 1.45 & 1.56 & $\mathrm{~B}$ & BB & BBB & BBB & BBB \\
\hline 127 & Aladin Lux & 0.58 & 0.51 & 0.78 & -0.58 & 0.41 & 1.2 & 1.47 & 1.93 & -0.41 & 1.25 & $\mathrm{BB}$ & $\mathrm{AAA}$ & AAA & $\mathrm{C}$ & BBB \\
\hline 128 & Inoma comp & 0.56 & 0.67 & 0.79 & 0.67 & 0.23 & 1.13 & 1.49 & 1.57 & 1.57 & 0.16 & BBB & AAA & $\mathrm{AA}$ & $\mathrm{AAA}$ & $\mathrm{C}$ \\
\hline 129 & Elvin & 0.1 & -0.61 & 0.44 & 0.55 & 0.08 & -0.56 & -1.44 & 0.25 & 0.47 & 0.06 & BBB & BB & BBB & A & BBB \\
\hline 130 & Križ̌́ik GBI & 0.37 & 0.44 & 0.31 & -0.36 & -0.09 & 0.71 & 0.88 & 0.64 & -2.46 & -1.95 & $\mathrm{~B}$ & BB & $\mathrm{B}$ & $\mathrm{C}$ & $\mathrm{C}$ \\
\hline 131 & Kiwa & -0.23 & 0.41 & -0.23 & 0.09 & 0.21 & -0.86 & 1.08 & -0.73 & -0.29 & -0.05 & C & CCC & $\mathrm{C}$ & $\mathrm{C}$ & $\mathrm{C}$ \\
\hline 132 & Inoteska & 0.67 & -0.18 & 0.18 & 0.9 & 2.8 & 0.98 & -0.85 & -0.48 & 0.64 & 4.1 & BBB & C & $\mathrm{BB}$ & BBB & $\mathrm{AAA}$ \\
\hline 133 & ZVT - Previs & 0.35 & 0.51 & 0.54 & 0.62 & 0.13 & 0.92 & 1.22 & 1.34 & 1.43 & -0.73 & $\mathrm{CCC}$ & BBB & $\mathrm{AA}$ & BBB & $\mathrm{C}$ \\
\hline 134 & Elektrosvit Vrakúń & 0.48 & 0.81 & -0.12 & 0.64 & 0.4 & 0.54 & 1.09 & -0.29 & 0.68 & 0.38 & & $\mathrm{AAA}$ & A & $\mathrm{AA}$ & $\mathrm{BB}$ \\
\hline 135 & JMT SK & 0.65 & 0.45 & 0.41 & 0.4 & -0.99 & 0.85 & -0.39 & -0.43 & -4.54 & -1.37 & $\mathrm{AA}$ & CCC & AAA & $\mathrm{C}$ & $\mathrm{CCC}$ \\
\hline 136 & Progyr & 0.95 & 1.05 & 0.96 & 1.21 & 0.64 & 2.15 & 2.39 & 2.09 & 2.3 & 1.24 & & $\mathrm{AAA}$ & AAA & $\mathrm{AAA}$ & $\mathrm{AA}$ \\
\hline 137 & OVP Orava & -0.41 & -0.43 & -1.58 & -1.47 & -0.88 & -1.3 & -1.35 & -3.56 & -3.25 & -2.19 & B & CCC & $\mathrm{C}$ & $\mathrm{C}$ & $\mathrm{C}$ \\
\hline 138 & $\begin{array}{l}\text { Panasonic AVC Ne- } \\
\text { tworks Slovakia }\end{array}$ & 1.09 & 1.26 & 1.69 & 10.81 & -19 & 2.41 & 2.21 & 2.48 & 9.6 & -26.58 & & $\mathrm{AAA}$ & $\mathrm{AAA}$ & $\mathrm{AAA}$ & \\
\hline
\end{tabular}

